\title{
Three dimensional organisation of basal bodies in Trypanosoma brucei
}

\author{
K Towers ${ }^{*}$, LC Hughes, S Vaughan \\ From First International Cilia in Development and Disease Scientific Conference (2012) \\ London, UK. 16-18 May 2012
}

Cilia and flagella are assembled from a basal body and assembly and duplication is tightly regulated with the cell cycle. A new basal body (called a pro-basal body) is formed orthogonal to the old basal body during S-phase and will assemble a cilium/flagellum in the next cell cycle. The basal body and pro-basal body are connected to each other and the pro-basal body must re-orientate and disengage from the basal body before forming a cilium/flagellum. There is still a poor molecular and ultrastructural understanding of the connections between the basal bodies and how these are re-organised during basal body duplication, re-orientation and segregation. The protozoan parasite Trypanosoma brucei is a well established model organism in which to study cilia/flagellum structure and function. The parasite is the causative agent of a fatal disease known as African sleeping sickness and the flagellum is a key virulence factor essential for cell viability, motility and transmission. We employed cellular electron tomography and serial thin section analysis to visualise the three dimensional organisation of basal bodies in T. brucei. This has enabled us to determine ultrastructural detail of basal body duplication throughout the cell cycle. We have characterised the connections which exist between basal bodies at various stages of the basal body maturation cycle and we now have greater understanding of how these connections are remodelled to allow successful re-orientation followed by timely segregation. These studies provide deeper understanding of how basal body duplication is regulated.

Submit your next manuscript to BioMed Central and take full advantage of:

- Convenient online submission

- Thorough peer review

- No space constraints or color figure charges

- Immediate publication on acceptance

- Inclusion in PubMed, CAS, Scopus and Google Scholar

- Research which is freely available for redistribution

Submit your manuscript at www.biomedcentral.com/submit
() Biomed Central

* Correspondence: ktowers@brookes.ac.uk

Oxford Brookes University, UK

(c) 2012 Towers et al; licensee BioMed Central Ltd. This is an Open Access article distributed under the terms of the Creative Commons 